\title{
The Determinants of the Usage of ICTs in Firms in Cameroon: Analysis by the economic Theory of the Firm
}

\author{
Alfred Jacquy MOUBEP \\ Members of the Laboratory of Applied and Theoretical Economics (LATE) \\ University of Douala \\ Faculty of Economics and Applied Management \\ POBox: 4032 Douala-Cameroun \\ Cameroon \\ Collins Penn CHI \\ Members of the Laboratory of Economics and Applied Management (LEAM) \\ University of Douala \\ Faculty of Economics and Applied Management \\ PO Box: 4032 Douala-Cameroun \\ Cameroon
}

\begin{abstract}
The objective of this study is to verify that the determinants of the usages of ICT in companies in Cameroon respond to the teachings of evolutionary theory, the theory of transaction costs, agency theory, the concept of strategic intelligence and verify that they are identical to those of companies in other countries. To do this, we estimate the probit simple and probit models ordered multivariate on a sample of 101 companies members of the Subcontracting and Partnership of Cameroon. Our econometric results show that the main determinants of the uses are: the size of the company, its dismemberment, its decentralization of responsibilities and its educational capital. The analysis of the results reveals fundamental lessons leading to the following policies to improve the competitiveness of enterprises through ICT: (1) sensitize leaders on the importance of decentralizing responsibilities, which makes it possible, thanks to ICT, to better control the actions of workers; (2) sensitize managers on the recruitment process integrating human capital and digital skills; (3) train managers to find e-business opportunities and improve their ability to seize them.
\end{abstract}

Keywords: second-order digital divide, ICT usage, competitiveness, e-business, Cameroon.

JEL classification : D22, D23, L63, L86, M21, O14, O35.

\section{Introduction}

Since their launching in the mid-1970s, ICTs have had a fast proliferation worldwide. According to Kossaï et al. (2010), their adoption has been generalised they have become one of the major vectors of social economic activity in developed countries as well as in emerging countries and developing countries.

Even though politicians and economists recognise the essential role of ICTs in the development (Dutta and Mia, 2009; UNCTAD $^{1}, 2009$ ) of developing countries, the limited access to ICTs by firms is a major obstacle for development (Dutta and Mia, 2009).

It is in this development objective that several developed and developing countries have applied government policies allocating national resources to the promotion of ICTs. That is, they had to encourage their firms to adopt these technologies (Gaulier et al., 2007; Amighini, 2005).

However, according to reports of the international telecommunications Union (ITU) since 2007 the IDI index of Cameroon is between 1.37 and 2.38 and it occupies between the $145^{\text {th }}$ and $154^{\text {th }}$ position. In 2017 Cameroon was the $149^{\text {th }}$ country out of 176 with an IDI index of 2.38 . It sub-index of access was 2.84 for the $150^{\text {th }}$ position just to name a few (UIT, 2017).

\footnotetext{
${ }^{1}$ United Nations Conference on Trade and Development, it is an organ of the United Nations, it was created in 1964. 
According to the report of the national institute of statistics (NIS) on the general survey of enterprises (RGE) of 2009 (NIS, 2009) globally, the rate of access to computers is $84 \%, 75 \%, 89 \%$ and $100 \%$ for very small firms, small firms, medium firms and large firms respectively.

Thus there still exists a problem of adoption of computers in all types of enterprises except large enterprises. The proportions of internet connection are 53\%, 53\%, 76\% and 95\% for very small firms, small firms, medium firms and large firms respectively. Thus, there is also the problem of internet adoption in enterprises.

According to the survey on the usage of ICT in enterprises in Cameroon financed by the council for the development of research in social science in Africa (CODESIA) and carried out in 2015 by the Laboratory of applied and theoretical economics (LETA) of the University of Douala on a sample of 1001 enterprises members of the out-sourcing and partnership market (BSTP) of Cameroon, 51\% of them do not have a website. In addition, out of the 24 uses of internet presented in the questionnaire they use about 6.

There is therefore a double digital divide in enterprises in Cameroon. In fact, among these enterprises we those with a first degree divide (divide of access/adoption) and those with a second degree divide (usage divide).

In digital economics, the theoretical debate is on the economic returns of ICT in general. It was highlighted by the aphorism of Solow in the New York Book Review of 12 July 1987 concerning computers that: 'the era of the computer is visible everywhere except in the statistics of productivity'. The importance of this 'paradox of productivity' or 'the paradox of Solow' was initiated by a simple study 'America's Technology Dilemma: A Profile of the Information Economy ', published by Steven Roach on 22 April 1987 in the economic letter of Morgan Stanley. He gave reasons for the low rate of growth of productivity in the American economy since 1973 (Triplett, 1999).

The most cited determinants in studies on the usage of ICTs are: the size of the enterprise and the level of education of the employees according to Litondo andNtale (2013);social capital for Deen-Swarray et al. (2013); the average age of his employees and the education capital for Tamokwé (2017). Shiels et al.(2003) found that the characteristics of enterprises and industries are contributive factors to the adoption and to exploit ICTs by SMEs.Litondo and Ntale (2013),found that the level of education is a major determinant of SMEs using mobile telephones for their business. This implies that education gives a base from which SMEs can undertake personal and professional development initiatives necessary for the use of mobile telephones by enterprises.

In developed countries as well as in developing countries several studies show that the epidemic effect (number of adopters in the region) plays a very important role in the inter-firm diffusion of ICTs (Fambeu, 2016; Ben Khalifa, 2016, 2014;Gallego et al., 2014;Arduini et al., 2010).

Several studies show that the utilisation of internet decreases with the age of the individual.In effect, Allegrezzaand Di Maria (2003) show that the probability to use the internet is weak for older persons more than 30 years of age and gets weaker for persons more than 50 years old. This can be explained by the fact that the internet is a recent phenomenon and that the youths adapt better to this technology than older persons. In conformity to De Koning andGelderblom (2006), in comparison to younger workers, older workers use ICTs less in their work, less complicated applications and more difficulties in using ICTs.

The studies on the usage of ICTs in enterprises in the developed and the developing countries mentioned above were carried out using econometric binary models with qualitative variables. For example, Ben Khalifa (2016) use the simple logit. In this study, based on the response given by the respondents, we have classified the level of usage of internet and web sites in an increasing order. Consequently, we have elaborated two ordered explained variables since data on the usage of computers does not exist, the variable «usage of computers » is a binomial qualitative variable. We are going to use the data of the survey financed by CODESRIA and carried out in 2015 by LETA of the University of Douala on a sample of 101 enterprises members of the BSTP of Cameroon. In order to do this, we use the simple probit model introduced by Bliss (1934) since the explained variable «usage of computers » is a qualitative binary variable. The univaried ordered probit model proposed in social sciences by McElveyet Zavoina (1975) for the variable «level of usage of internet» which is a multinomial qualitative variable.

These results show that social capital of the enterprise, his sector of activity, its size, its ownership of subsidiaries abroad and belonging to a group significantly and positively affects the usage of computers in enterprises of our sample.

The results of the level of usage of internet in enterprises in the table below show that only some factors are determining notably the usage of internet by the CSP of the average white collar worker, the average age of the workers, the average age of the average white collar worker, the branches in the country, the computer networks and the exportations significantly explain the usage of internet in the enterprises of our sample. 
From this information, we find that policies aimed at competitiveness of enterprises through the ICTs have to be principally focused on:

- Sensitise management on the process of recruitment that integrates human capital and competence in ICTs ;

- Training managers to identify the opportunities of e-business and to improve their capacity to master them ;

- Improve academic and computer training so as to make students respond better to the expectations of the enterprises If the adoption and the usage of ICTs in enterprises are largely explained in developed countries, it is not often studied in developing countries. In fact, in developing countries ICTs have a systemic character since their adoption is conditioned by an environmental context that is different from that of developed countries. These differences are amongst others available infrastructure, the quality and the availability of qualified personnel, the size of the enterprise, the profile of the manager, etc. For these reasons and many others it is interesting to verify that the determinants of usage of ICTs in enterprises in Cameroon correspond to the information required by the evolutionist theory, the theory of transaction costs, the agency theory, the notion of strategic surveillance and to verify that they are identical to those of enterprises of other countries.

The rest of the article is organised as follows. A review of theoretical and empirical literature is presented in section 2. The methodology of the research is presented in section 3. Section 4 presents the results and their interpretations. The fifth section deals with the conclusion and the main recommendations.

\section{Review of Literature on Usage of ICTs in Enterprises}

The expression «Information and communication technology» is used in several instances which correspond to the domain of telematics. According to the online Larousse dictionary, ICTs are a set of techniques and computer equipment that enable electronic distance communication (telephone, internet, etc). According to the Great terminology online dictionary of OQLE (the Quebec bureau of French language), ICTs are a « set of technologies resulting to the convergence of computer sciences and the advanced multimedia techniques and telecommunications which have lead to the emergence of more efficient means of communication, by improving their treatment, their memory, diffusion and the exchange of information ». This definition takes into account the digital convergence as a whole what the other definition did not do. According to Diagne andBirba (2008), fundamentally ICTs are tools of information manipulation that is a set of variety of products, applications and services that are used to produce, store, treat, distribute and exchange information. We distinguish the «old» ICTs (radio, television, telephone) and the «new» ICTs (computers, satellites and Internet). The two are now combined into an impressive infrastructure that is made up of interconnected telephone services, normalized computer materials, the internet, the radio and the television. Studies on the determinants of the usage of ICTs in enterprises have enabled to identify several factors in favour of usage. The most cited are: the size of the enterprise, the level of education of employees, social capital. and the age of the employees. According to Oyelaran-Oyeyinka andLal (2004), there exist a positive correlation between enterprises using advanced technologies and the level of education of entrepreneurs and between the different modes of apprenticeship and the complexity of the utilization of ICTs. Equally, there exist an association between the level of utilization of ICTs and the national level of technological capacity. These authors do not have economic theories of the firm as theoretical basis. In other words, they use only descriptive statistics and simple linear regression to analyse the different links between the variables. .

According to Litondo and Ntale (2013), the level of education is a major determinant of SMEs using mobile telephones for their business. We notice that they use the simple logit model to estimate the factors; in addition, they have not presented the theories which talk of the determinants of usage.

According to Tamokwe (2017) there is conformity between the impacts of age and education on the utilisation of ICTs and the anticipations of the theory when we are in an environment where households find good formulas to obtain adhesion of the employees to the corporate culture. It should be noted that the author uses only the number of operations carried out with the aide of the internet for the model of utilization of ICTs.

In this article we use the economic theories of the firm and the econometrics of qualitative variables which highly recommended for studies related to qualitative variables.

\section{2-Methodology}

\subsection{Source of data}

We use data of the survey relative to the usage of ICTs in enterprises in Cameroon. This survey was financed by CODESRIA, carried out in 2015 by the research group in Theoretical and Applied economics (GRETA) which became LETA in 2017 on a sample of 101 enterprises members of the BSTP of Cameroon. 
According to (2017), the BSTP is operational since 2011. It was created by the government of Cameroon with the support of the European Union (EU) and the United Nations Organisation for Industrial development. It fundamental mission is to raise local enterprises to the level of international competition through out-sourcing and partnerships with other local enterprises and multinationals.

\subsection{Econometric Model}

\subsubsection{The simple probit Model}

We assume that the usage of computers in an enterprise follows a normal distribution that is centered and reduced. We consider

$$
\mathrm{Y}_{i}=\mathrm{F}\left(\beta \mathrm{X}_{i}\right)+\varepsilon_{i}
$$

Where $Y_{i}$, is the binary variable expressing the usage of a computer in the enterprise. We recall that the variable $Y_{i}$ takes the value 1 if the individual uses a computer in the enterprise and 0 if not.F $(\beta X)$ the function of repartition of the normal distribution $\mathrm{N}(0,1)$, with Xthe vector of the parameters.

We assume that the errors $\varepsilon_{i}$ follow the same distribution as $\mathrm{Y}$ thus they are normal centered and reduced. This implies that their mathematical experience is null $(\mathrm{E}(\varepsilon)=0)$.

\subsubsection{The Ordered Probit Model}

We assume that the level of usage of the internet depends on the value taken by an unobservable continuous latent variable $y_{i}^{*}$ such as : $y_{i}^{*}=\beta x_{i}+\varepsilon_{i}$ (Greene, 2003). This variable is distributed according to the law $\mathrm{N}\left(0, \sigma^{2}\right) \cdot x_{i}$ designating the vector of endogenous variables, $\beta$ the vector of parameters and $\varepsilon_{i}$ a residual error term that follows a normal distribution.

The variable nui is determined by the model:

Where the $c_{i} \in \mathbb{R}$.

$$
\text { nui }_{i}=\left\{\begin{array}{cl}
\text { level } 1 & \text { if } \text { nui }_{i}^{*}<c_{1} \\
\text { level } 2 & \text { if } c_{1} \leq \text { nui i }_{i}^{*}<c_{2} \\
\text { level } 3 & \text { if } c_{2} \leq \text { nui }_{i}^{*}<c_{3}(5) \\
\text { level } 4 & \text { if } c_{3} \leq \text { nui }_{i}^{*}<c_{4} \\
\text { level } 5 \text { if nui }{ }_{i}^{*}>c_{4}
\end{array}\right.
$$

\subsection{Definition of variables and descriptive statistics :}

The independent variables are chosen in reference to the literature review and according to information from our data. .

Table1:Definition of variable and descriptive statistics are presentedat the end of article

\section{Results and Interpretations}

\subsection{Results and interpretations of the model of usage of computers}

The resultsof the estimation are presented in tables 2 at the end of article.

These results show that the social capital of the enterprise (this factor was also found by the authors Deen-Swarray et al., 2013), its tertiary sector of activity, its size, the possession of subsidiaries abroad and his belonging to a group affects positively and significantly affects the usage of computers in enterprises of our sample. As we presented above, the theory of transaction cost is used especially for its information relative to the internal coordination of activities. The usual tendency is a positive relation between the usage of ICTs in an enterprise and its size, its subsidiaries and it's belonging to a group of enterprises. The factors linked to the theory of transaction cost obtained in this study are significantly positive. These determinants are also found by some authors such as Ben Khalifa (2014). Globally the significance of the effects is same as those we predicted.

According to our calculations of the marginal effects, an increase in $1 \%$ of the social capital of the enterprise increases $0.02537 \%$ of chances of using the computer in the enterprise. Equally an increase in $1 \%$ of the size of theenterprise, increases $0.5253 \%$ probability that a computer is used in the enterprise. Belonging to a group of enterprises increases the chances of usage of computers by $24.9 \%$. According to the results, the worker's CSP positively and significantly affects the usage of computers. But, the status of the average white collar worker negatively and significantly affects the usage of computers. Thus the average white collar workers the lesser the use of computers. 
This can be explained by the fact that these white collar worker are occupied by other very important activities or that the enterprises has other equipment that play the same role as the computer. As for the average age of the worker, the average age of a blue collar worker and average age of a top white collar worker, the second cycle secondary school level of education, ' $A$ ' level +2 , most men and the total number of permanent workers, the results are significant but not all positive.

The average age of CSP blue collar workers and top white collar workers is negative. Thus, if the age of a blue or top white collar worker is more than 30 years it is less likely for the firm to use computers. Studies such as that of Tamokwé (2017) suggest the same results.

Clearly, the more the size of the enterprise in terms of the number of permanent employees is high the more the enterprise used computers, in other words if the number employees increase by $1 \%$ the usage of computers increase but by $0.5253 \%$. Thus, large firms use enough computers. Also, the higher the average age of the blue or top white collar worker the lesser the use of computers; if there are more men in the enterprise with respect to women it is more likely for computers to be used in the enterprise. With respect to the level of education, the second cycle secondary level of education, 'A' level + 2 positively impacts the usage of the computer in the enterprise. Consequently, globally the characteristics of employees positively affect the usage of computers in enterprises in Cameroon.

The results of the characteristics of the manager reveal that: managers who are less than 30 years of age negatively affect the usage of computers in their respective enterprises. If the manager is a man, then there is a $12.24 \%$ chance that computers will be used in the enterprise under their control.

We know that the agency theory focuses first on the construction of a monitoring and incentive system that prevent the agent from having an opportunistic behaviour. According to Pérez (2005), it is generally admitted that ICTs help in the decentralization of the firm when they enable top management for example to communicate directly with employees below the hierarchy without passing through line managers. Thus, there exist a positive relation between the usage of ICTs and the degree of decentralization in a firm.

Lesca(1994) precise that «la strategic surveillance is to strategic management what the radar is to the navy ». The analysis of the notion of strategic surveillance lead to the hypothesis of the existence of a positive relation between the adoption of ICTs by the firms and respectively: the competitive intensity that they face, the extent of the use of information technology in the branch they belong to and the distance of the markets in which they intervene.

When the average level of competition increases by $1 \%$, the usage of computers in the enterprise increases by $27.10 \%$ equally when the level of fierce competition increases by $1 \%$ the usage of computers in the firms of our sample increase by $10.59 \%$. The levels of average and fierce competition with respect to the weak level encourage enterprises in Cameroon to use computers.

\subsection{Results and interpretations of the models of the level of usage of internet}

The results of the estimation are presented in table 3 at the end of article.

The results of the level of usage of internet in enterprises in the table above show that only some factors are determinant notably the usage of the internet by the CSP of average white collar workers, the average age of the workers, the average age of average white collar workers, braches in the country, a network of computers and exports significantly explain the usage of internet in the enterprise of our sample. Thus, the factors linked to the theories of transaction costs, agency, evolutionists and the notion of strategic surveillance are the determinants in this model. Nevertheless, the significance of the effects is not exactly those we predicted. When we take the variable average age of the CSP of the average white collar worker it is significant and positive in sign which implies that the level of usage of internet evolves in the same direction as the average age of white collar workers which is paradoxical. This positive sign can be due to the fact that the employees who use internet technology are few and consequently when the average white collar workers get older they continue to use the internet.

It is seen that the level of education does not affect the usage of the internet technology as well as the level of decentralization of responsibilities and the levels of competition. This nonsignificance can be explained by the fact that enterprise which use the internet in our sample the technology less often. Can one think that enterprises in Cameroon do not see the importance of internet technology? Or that this technology has not penetrated enough into their habits? Whatever the case, it is clearly seen that firms in Cameroon do not use the internet enough.

\section{Conclusion and Recommandations}

The objective of this study was to verify the determinants of the usage of ICTs in Cameroon that respond to the evolutionist, transaction cost and agency theories and the notion of strategic surveillance and to find out if they are identical to those of enterprises of other countries. 
Globally, from the two models of usage of ICTs in enterprises we can retain that the global characteristics of the enterprise, the manager and the employees unarguably affect the usage of ICTs. For example the size of the enterprise as the total number of permanent employees positively and significantly impacts the usage of computers (the internet) in the firms. This positive relation between the usage of ICTs and the size of the enterprise was equally found by Katrak (1985) ; Braga and Willmore (1991) ; and Kumar and Siddharthan (1997). These authors even concluded that the size of the firm significantly increases the probability of using advanced technology.

Generally all these results lead to the following information:

- From the two ICTs chosen in our study, the internet technology is less used by 101 enterprises of ours ample. Since among the 92 enterprises which use the internet only about six internet usages are carried out by most of them.

- The level of education does not affect the usage of internet in the enterprises.

- The level of knowledge and consciousness of managerial and business opportunities offered by ICTs remains very small in enterprises.

From this information, it can be deduced that the policy aimed at the competitiveness of enterprises through ICTs have to include the following:

- Sensitise managers on the process of recruitment that integrates human capital and competence in ICTs ;

- Train managers to identify e-business opportunities and improve their ability to take advantage of them ;

- Improve educative and computer science trainings so as to make students perform better so that they can respond to the expectations of the enterprises;

The data that we have used are rich in information. However, several variables such as competence in ICTs and social capital are not rich in information. Future studies on the usage of ICTs should ensure that these variables appear in the data. Future studies should equally focus on mobile payments, e-commerce, etc.

\section{References}

Amighini, A. (2005).China in the International Fragmentation of Production: Evidence from the ICT Industry.The European Journal of Comparative Economics, 2, 2, 203-219.

Ansoff, H.I. (1975). Managing Strategic Surprise by Response to Weak Signals.California Management Review, 18, 2, 21-33.

Arrow, K. (1971), Essays in the Theory of Risk Bearing, Chicago: Markham, 278 p.

Coase, R.H. (1937). The nature of the firm. Economica,4, 16,386-405.

Deen-Swarray, M..,Moyo, M. Et Stork, C. (2013).ICT Access and Usage among Informal Businesses in Africa.Info, 15, $5,52-68$.

Dutta, S.,CtMia, I. (2009).The Global Information Technology Report 2008-2009. Mobility in a Networked World, Geneva: World Economic Forum and INSEAD, 406 p.

Lesca, H. (2001). «Veille stratégique : Passage de la notion de signal faible à la notion de signe d'alerte précoce ».Communication au séminaire Veille Stratégique Scientifique et Technologique (VSST), 7p.

Litondon, K. O., EtNtale, J.F.(2013).Determinants of Mobile Phone Usage for E-Commerce among Micro and Small Enterprises in the Informal Sector of Kenya. International Journal of Applied Science and Technology, 3, 6, 16-23.

Obiri-Yeboah, K., Owusu-Ansah W. EtOdei-Lartey, E. O. (2013).«Factors that Drive Internet Usage among Small and Medium Scale Enterprises: Evidence from Ghana».International Journal of Management and Marketing Research, 6, 2, 21-37.

TamokwéPiaptié, G.B. (2017). « Les déterminants de l'adoption et de l'utilisation des TIC dans les entreprises au Cameroun : analyse via les théories économiques de la firme et les notions dethin/thick-integration ».Document de travail, $23 \mathrm{p}$.

Triplett, J.E. (1999). The Solow Productivity Paradox: What do Computers do to Productivity?,Canadian Journal of Economics, 32, 2, 309-334. 
Table 1: Definition of variable and descriptive statistics

\begin{tabular}{|l|l|l|l|l|l|l|}
\hline Variables & \multicolumn{1}{|c|}{ Definition } & $\begin{array}{c}\text { Freque } \\
\text { ncy }\end{array}$ & \multicolumn{1}{|c|}{ Mean } & $\begin{array}{l}\text { Standard } \\
\text { deviation }\end{array}$ & Min & Max \\
\hline sec22 & 1 if the enterprise is in the secondary sector 0 if not s & 101 & 0.4752475 & 0.5018777 & 0 & 1 \\
\hline sec33 & 1 if the enterprise is in the Tertiary sector 0 if not & 101 & 3.465347 & 0.4935224 & 0 & 1 \\
\hline eff & The enterprise has several permanent employees & 101 & 23.41584 & 32.36426 & 1 & 227 \\
\hline agec & $\begin{array}{l}\text { 1 if the manager of the enterprise is less than 30 years } \\
\text { O if not }\end{array}$ & 101 & 3.564356 & 2.447104 & 1 & 9 \\
\hline sexc & 1 if the manager of the enterprise is a man 0 if not & 101 & 0.8712871 & 0.3365521 & 0 & 1 \\
\hline dec2 & 1 if the level of decentralisation is average s 0 if not & 101 & 1 & 0.8246211 & 0 & 6 \\
\hline con22 & 1 if the level of competition is average 0 if not & 101 & 0.3168317 & 0.4675616 & 0 & 1 \\
\hline deme & 1 if the enterprise has subsidiaried abroad s if not & 101 & 1.544554 & 0.7419535 & -1 & 2 \\
\hline grp & 1if the enterprise is in a group of enterprises 0 if not & 101 & 2.138614 & 0.8605777 & 1 & 8 \\
\hline reso2 & 1 if the enterprises are interconnected 0 if not & 101 & 1.722772 & 0.4498625 & 1 & 2 \\
\hline
\end{tabular}

Source:table elaborated by authors

Table 2: Results of the estimation of the model of usage of computers

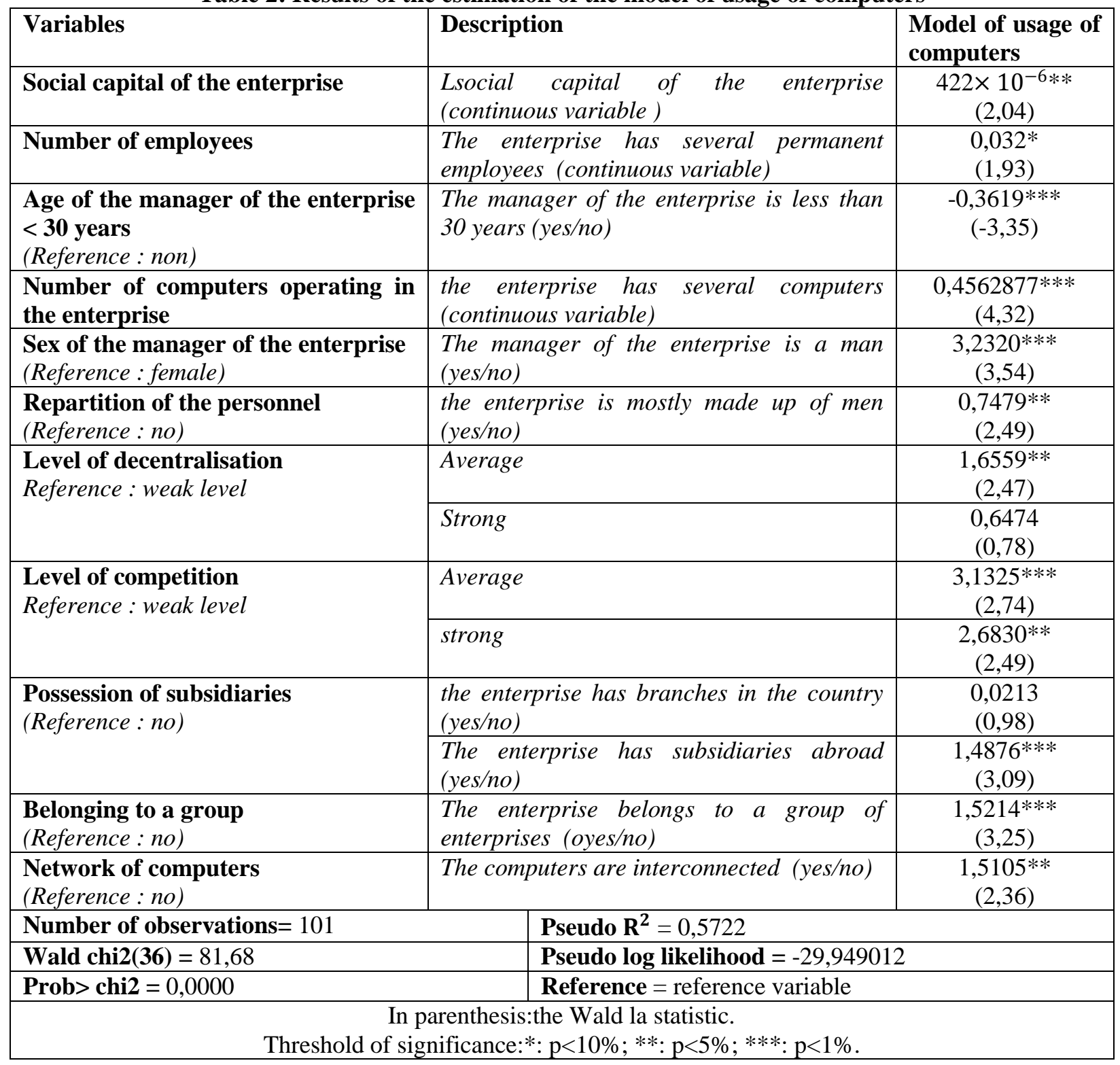


Source: table elaborated by authors

Table 3: Results of the estimation of the model of usage of computers in enterprises

\begin{tabular}{|c|c|c|}
\hline Variables & Description & $\begin{array}{l}\text { Model of level of } \\
\text { internet usage }\end{array}$ \\
\hline Social Capital of the enterprise & the social capital of the enterprise & $\begin{array}{c}-1604 \times 10^{-7} \\
(-1.08)\end{array}$ \\
\hline Number of employees & $\begin{array}{l}\text { the enterprise has several employees } \\
\text { (continuous variable) }\end{array}$ & $\begin{array}{c}-266 \times 10^{-5} \\
(-0,49)\end{array}$ \\
\hline $\begin{array}{l}\text { Age of the manager of the enterprise } \\
<30 \text { years } \\
\text { (Reference : no) }\end{array}$ & $\begin{array}{l}\text { The manager of the enterprise is less } \\
\text { than } 30 \text { years (yes/no) }\end{array}$ & $\begin{array}{c}0,087177 \\
(1,41)\end{array}$ \\
\hline $\begin{array}{l}\text { Number of computers operating in } \\
\text { the enterprise }\end{array}$ & $\begin{array}{l}\text { the enterprise has many computers } \\
\text { (continuous variable) }\end{array}$ & $\begin{array}{c}-0,0186557 \\
(-0,71)\end{array}$ \\
\hline $\begin{array}{l}\text { Gender of the manager of the } \\
\text { enterprise }\end{array}$ & $\begin{array}{l}\text { The manager of the enterprise is a man } \\
\text { (yes/no) }\end{array}$ & $\begin{array}{c}-0,4655194 \\
(-0,57)\end{array}$ \\
\hline $\begin{array}{l}\text { The level of education of the } \\
\text { manager of } \\
\text { (Reference: } n o \text { ) }\end{array}$ & $\begin{array}{l}\text { The manager of the enterprise has at } \\
\text { least the 'A'levels (yes/no) }\end{array}$ & $\begin{array}{c}-0,0026172 \\
(-0,07)\end{array}$ \\
\hline Repartitionof personnel & $\begin{array}{l}\text { The firm is mostly made up of men } \\
\text { (yes/no) }\end{array}$ & $\begin{array}{c}0,0620027 \\
(0,63)\end{array}$ \\
\hline \multirow[t]{2}{*}{$\begin{array}{l}\text { Possession of subsidiaries } \\
\text { (Reference : no) }\end{array}$} & $\begin{array}{l}\text { the enterprise has other subsidiaries in } \\
\text { the host country (yes/no) }\end{array}$ & $\begin{array}{c}0,027954 * * \\
(2,43)\end{array}$ \\
\hline & $\begin{array}{l}\text { The enterprise has subsidiaries abroad } \\
\text { (yes/no) }\end{array}$ & $\begin{array}{c}-0,1301678 \\
(-0,43)\end{array}$ \\
\hline $\begin{array}{l}\text { Belonging to a group } \\
\text { (Reference : no) }\end{array}$ & $\begin{array}{l}\text { The enterprise belongs to a group of } \\
\text { enterprises (yes } / \text { no) }\end{array}$ & $\begin{array}{c}-0,2598074 \\
(-1,32)\end{array}$ \\
\hline $\begin{array}{l}\text { Having a computer network } \\
\text { (Reference: no) }\end{array}$ & $\begin{array}{l}\text { The computers are inter connected } \\
(\text { yes } / \text { no) }\end{array}$ & $\begin{array}{c}0,5684985^{*} \\
(1,64)\end{array}$ \\
\hline \multicolumn{2}{|c|}{\begin{tabular}{|l|l} 
Number of observations $=92$ & Cut $1=-5,924361 * * *$ \\
\end{tabular}} & \\
\hline \multicolumn{2}{|c|}{\begin{tabular}{|l|l} 
Wald chi2 $(36)=94,04$ & Cut $2=-4,654741 * * *$ \\
\end{tabular}} & \\
\hline \multicolumn{2}{|c|}{\begin{tabular}{|l|l} 
Prob $>$ chi $2=0,0000$ & Cut $3=-3,153489 * * *$ \\
\end{tabular}} & \\
\hline \multicolumn{2}{|c|}{ Pseudo $\mathbf{R}^{2}=0,2120$} & \\
\hline \multicolumn{3}{|c|}{ Pseudo log vraisemblance $=-94,601217$} \\
\hline \multicolumn{3}{|c|}{$\begin{array}{l}\text { In parenthesis : Wald statistic } ; \text { Reference }=\text { reference variable } \\
\text { Threshold of significance:*: } p<10 \% ; * *: p<5 \% ; * * *: p<1 \% .\end{array}$} \\
\hline
\end{tabular}

Source: table elaborated by authors

Appendix 1: Results of the estimation of the model of usage of computers in enterprises 


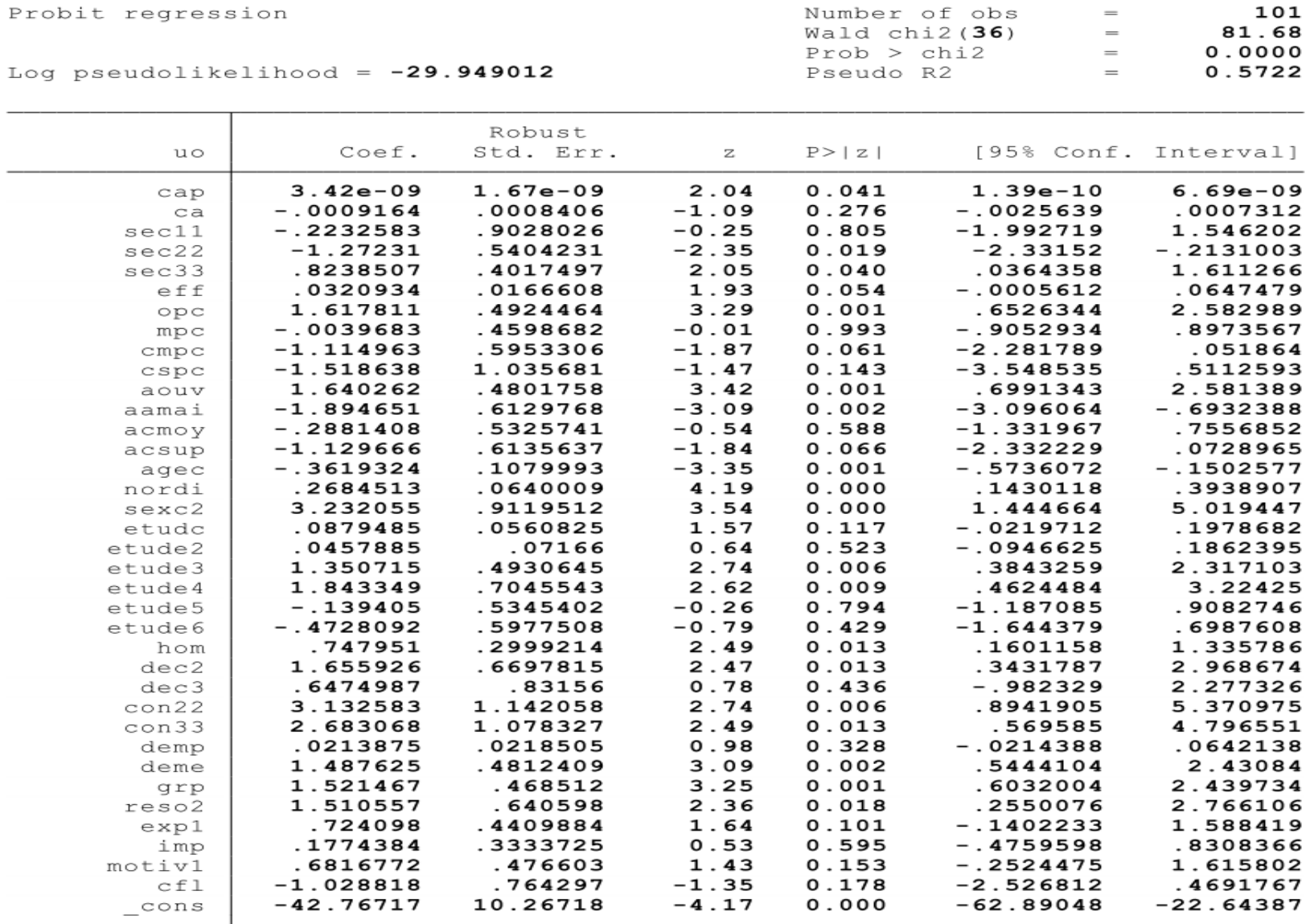

Appendix 2:Marginal effects of the model of usage of computers inenterprises 
Average marginal effects

Number of obs

101

Model VCE : Robust

Expression : $\operatorname{Pr}($ uo), predict()

$d y / d x$ w.r.t. : cap ca sec11 sec22 sec33 eff opc mpc cmpc cspc aouv aamai acmoy acsup agec nordi sexc2 etudc etude2 etude3 etude 4 etude5 etude 6 hom dec2 dec3 con22 con33 demp deme grp reso2 exp1 imp motiv1 cfl

\begin{tabular}{|c|c|c|c|c|c|c|}
\hline & $\mathrm{dy} / \mathrm{dx}$ & $\begin{array}{l}\text { elta-metho } \\
\text { Std. Err. }\end{array}$ & $z$ & $\mathrm{P}>|\mathrm{z}|$ & [95\% Conf. & Interval] \\
\hline cap & $5.59 e-10$ & $2.73 e-10$ & 2.05 & 0.040 & $2.44 \mathrm{e}-11$ & $1.09 e-09$ \\
\hline $\mathrm{ca}$ & -.00015 & .0001361 & -1.10 & 0.270 & -.0004167 & .0001167 \\
\hline sec11 & -.0365439 & .1482007 & -0.25 & 0.805 & -.327012 & .2539241 \\
\hline $\sec 22$ & -.2082576 & .0848872 & -2.45 & 0.014 & -.3746335 & -.0418816 \\
\hline $\sec 33$ & .1348517 & .0619499 & 2.18 & 0.029 & .0134321 & .2562713 \\
\hline eff & .0052532 & .002516 & 2.09 & 0.037 & .000322 & .0101844 \\
\hline opc & .2648108 & .0705711 & 3.75 & 0.000 & .1264939 & .4031277 \\
\hline $\mathrm{mpc}$ & -.0006496 & .0752693 & -0.01 & 0.993 & -.1481746 & .1468755 \\
\hline $\mathrm{cmpc}$ & -.1825022 & .0944597 & -1.93 & 0.053 & -.3676398 & .0026355 \\
\hline $\operatorname{cspc}$ & -.2485776 & .1600433 & -1.55 & 0.120 & -.5622567 & .0651015 \\
\hline aouv & .2684855 & .0661968 & 4.06 & 0.000 & .1387423 & .3982288 \\
\hline aamai & -.3101252 & .0842885 & -3.68 & 0.000 & -.4753275 & -.1449229 \\
\hline acmoy & -.0471642 & .0870805 & -0.54 & 0.588 & -.2178389 & .1235105 \\
\hline acsup & -.184909 & .0968481 & -1.91 & 0.056 & -.3747277 & .0049098 \\
\hline agec & -.0592428 & .0147013 & -4.03 & 0.000 & -.0880567 & -.0304288 \\
\hline nordi & .0439413 & .0087652 & 5.01 & 0.000 & .0267619 & .0611208 \\
\hline $\operatorname{sexc} 2$ & .5290376 & .1397272 & 3.79 & 0.000 & .2551773 & .8028979 \\
\hline etudc & .0143958 & .0095064 & 1.51 & 0.130 & -.0042364 & .033028 \\
\hline etude2 & .0074949 & .0116944 & 0.64 & 0.522 & -.0154257 & .0304154 \\
\hline etude 3 & .2210912 & .0801457 & 2.76 & 0.006 & .0640085 & .3781738 \\
\hline etude 4 & .3017279 & .1085072 & 2.78 & 0.005 & .0890577 & .5143981 \\
\hline etude 5 & -.0228184 & .0876828 & -0.26 & 0.795 & -.1946735 & .1490367 \\
\hline etude 6 & -.0773916 & .0974026 & -0.79 & 0.427 & -.2682971 & .1135139 \\
\hline hom & .122428 & .0493688 & 2.48 & 0.013 & .0256671 & .219189 \\
\hline dec 2 & .2710496 & .0939635 & 2.88 & 0.004 & .0868845 & .4552147 \\
\hline $\operatorname{dec} 3$ & .1059856 & .133489 & 0.79 & 0.427 & -.155648 & 3676191 \\
\hline $\operatorname{con} 22$ & .5127555 & .166388 & 3.08 & 0.002 & .1866411 & .8388699 \\
\hline $\operatorname{con} 33$ & .4391769 & .1585699 & 2.77 & 0.006 & .1283856 & .7499682 \\
\hline demp & .0035008 & .0036353 & 0.96 & 0.336 & -.0036242 & .0106258 \\
\hline deme & .2435013 & .075254 & 3.24 & 0.001 & .0960063 & .3909964 \\
\hline grp & .2490407 & .0727662 & 3.42 & 0.001 & .1064216 & 3916598 \\
\hline reso 2 & .2472548 & .0926161 & 2.67 & 0.008 & .0657305 & .4287792 \\
\hline exp1 & .1185237 & .0699016 & 1.70 & 0.090 & -.018481 & .2555284 \\
\hline imp & .0290439 & .0543227 & 0.53 & 0.593 & -.0774265 & .1355144 \\
\hline motiv1 & .11158 & .076197 & 1.46 & 0.143 & -.0377633 & .2609234 \\
\hline $\mathrm{cfl}$ & -.1684016 & .1219555 & -1.38 & 0.167 & -.4074299 & .0706267 \\
\hline
\end{tabular}


Appendix 3 : Results of theestimation of the model of the level of usage of internet in enterprises

ordered probit regression

Log pseudolikelihood $=-94.601217$
Number of obs

Wald chi2(36)

Prob > chi2

Pseudo R2
94.07

0.0000

0.2120

\begin{tabular}{|c|c|c|c|c|c|c|}
\hline nui & Coef. & $\begin{array}{l}\text { Robust } \\
\text { Std. Err. }\end{array}$ & $z$ & $\mathrm{P}>|\mathrm{z}|$ & [95\% Conf. & Interval] \\
\hline cap & $-1.30 e-09$ & $1.20 e-09$ & -1.08 & 0.279 & $-3.66 e-09$ & $1.06 \mathrm{e}-09$ \\
\hline $\mathrm{ca}$ & .0001711 & .0005508 & 0.31 & 0.756 & -.0009085 & .0012507 \\
\hline $\sec 11$ & -1.630903 & .6524131 & -2.50 & 0.012 & -2.909609 & -.3521968 \\
\hline $\sec 22$ & .3490225 & .321308 & 1.09 & 0.277 & -.2807295 & .9787746 \\
\hline $\sec 33$ & -.1502405 & .1678834 & -0.89 & 0.371 & -.479286 & .1788051 \\
\hline eff & -.0026663 & .0053987 & -0.49 & 0.621 & -.0132476 & .0079151 \\
\hline uio & -.1174844 & .567204 & -0.21 & 0.836 & -1.229184 & .9942151 \\
\hline uiam & .0504284 & .3573754 & 0.14 & 0.888 & -.6500146 & .7508714 \\
\hline uicm & -1.261431 & .5069071 & -2.49 & 0.013 & -2.25495 & -.2679111 \\
\hline uics & -.2353059 & .3051674 & -0.77 & 0.441 & -.8334231 & .3628113 \\
\hline aouv & 1.023587 & .2987633 & 3.43 & 0.001 & .438022 & 1.609153 \\
\hline a amai & -.0633392 & .3412787 & -0.19 & 0.853 & -.7322331 & .6055547 \\
\hline acmoy & .8643536 & .3290147 & 2.63 & 0.009 & .2194967 & 1.509211 \\
\hline acsup & .1277591 & .3043883 & 0.42 & 0.675 & -.4688309 & .7243492 \\
\hline agec & .0871777 & .0619281 & 1.41 & 0.159 & -.0341992 & .2085545 \\
\hline nordi & -.0186557 & .0261137 & -0.71 & 0.475 & -.0698376 & .0325262 \\
\hline $\operatorname{sexc} 2$ & -.4655194 & .8155242 & -0.57 & 0.568 & -2.063918 & 1.132879 \\
\hline etudc & -.0026172 & .0363932 & -0.07 & 0.943 & -.0739465 & .068712 \\
\hline etude 2 & .0220666 & .0530702 & 0.42 & 0.678 & -.0819491 & .1260823 \\
\hline etude 3 & -.3363355 & .2837157 & -1.19 & 0.236 & -.8924082 & .2197371 \\
\hline etude 4 & -.1320523 & .354321 & -0.37 & 0.709 & -.8265088 & .5624042 \\
\hline etude 5 & .2323976 & .4298421 & 0.54 & 0.589 & -.6100774 & 1.074873 \\
\hline etude 6 & .3139972 & .4023425 & 0.78 & 0.435 & -.4745796 & 1.102574 \\
\hline hom & .0620027 & .0990985 & 0.63 & 0.532 & -.1322268 & .2562321 \\
\hline $\operatorname{dec} 2$ & -.0544475 & .1774923 & -0.31 & 0.759 & -.402326 & .293431 \\
\hline $\operatorname{dec} 3$ & -.3000507 & .372895 & -0.80 & 0.421 & -1.030912 & .4308102 \\
\hline $\operatorname{con} 22$ & -.5564481 & .8109184 & -0.69 & 0.493 & -2.145819 & 1.032923 \\
\hline $\operatorname{con} 33$ & -.3647887 & .8413594 & -0.43 & 0.665 & -2.013823 & 1.284245 \\
\hline demp & .027954 & .0114855 & 2.43 & 0.015 & .0054429 & .0504651 \\
\hline deme & -.1301678 & .3046906 & -0.43 & 0.669 & -.7273503 & .4670147 \\
\hline grp & -.2598074 & .1973382 & -1.32 & 0.188 & -.6465833 & .1269684 \\
\hline reso2 & .5684985 & .3457913 & 1.64 & 0.100 & -.1092399 & 1.246237 \\
\hline exp1 & .687234 & .2714807 & 2.53 & 0.011 & .1551417 & 1.219326 \\
\hline impl & .3674627 & .4575449 & 0.80 & 0.422 & -.5293089 & 1.264234 \\
\hline motiv1 & .5655044 & .3512244 & 1.61 & 0.107 & -.1228826 & 1.253892 \\
\hline cfl & -.4419238 & .5227353 & -0.85 & 0.398 & -1.466466 & .5826185 \\
\hline /cut 1 & -5.924361 & 6.961861 & & & -19.56936 & 7.720635 \\
\hline /cut2 & -4.654741 & 6.942411 & & & -18.26162 & 8.952135 \\
\hline$/ \operatorname{cut} 3$ & -3.153489 & 6.932521 & & & -16.74098 & 10.434 \\
\hline /cut 4 & -2.379791 & 6.86925 & & & -15.84327 & 11.08369 \\
\hline
\end{tabular}

